\title{
Occupation of father at time of birth of children dying of malignant diseases*
}

\author{
JACQUELINE FABIA AND TRUONG DAM THUY \\ Department of Social and Preventive Medicine, Medical School, Laval University, Quebec City, Canada
}

\section{SUMMARY}

Occupation of father at time of birth was ascertained for a series of 386 children who died of malignant disease before age 5 during the years 1965-70 in the province of Quebec and a control group of 772 children whose birth registration immediately preceded and followed that of each case in the official files. The comparison of cases with controls showed a significant excess of fathers in hydrocarbon-related occupations among the cases with relative odds of $2 \cdot 1$. These occupations included, in particular, motor-vehicle mechanics, machinists, miners, and painters. On the other hand, cases and controls did not differ with regard to place of residence of parents or mean paternal age. The possible role of father's occupation in the risk of malignant disease of his offspring seems to deserve further investigation.

\section{INTRODUCTION}

In previous studies of birth characteristics of children dying of malignant diseases (Stewart, Webb, and Hewitt, 1958; Pinkel and Nefzger, 1959; Githens, Elliot, and Saunders, 1965; Fasal, Jackson, and Klauber, 1971) father's occupation was used only as an index of socioeconomic class.

In reviewing, for other purposes, a small sample of birth and death certificates of Quebec children the impression emerged of a large number of fathers in petrol-related occupations when the cause of death was cancer.

The purpose of this study is to investigate the possible risk of malignant disease in childhood associated with specific types of occupation of the father.

- This study was supported in part by a grant from the University of Montreal.

\section{MATERIAL AND Methods}

Children who died of malignant diseases under the age of 5 in the province of Quebec during the years 1965-70 were traced from three independent sources-death certificates, hospital insurance data, and hospital records, in particular those of the two paediatric hospitals in the province, the Montreal Children's and Sainte-Justine.

Birth certificates were found at the Quebece population register for 386 out of 402 patients? ascertained.

A control group was assembled comprising 772 children whose birth registration immediately preceded and followed that of each case in the official files.

Information with regard to residence of mother at the time of birth, age of parents, and occupation of father was obtained from birth certificates.

Occupations of fathers were grouped according to guidelines given by a specialist in industrial hygiene unaware of the numbers of cases and controls involved. Three groups with potential exposure to hydrocarbons were identified: the first included motor-vehicle mechanics and servicestation attendants exposed to petrol and oil; the second comprised machinists, miners, and lumbermen also exposed to petrol and oil; and the third painters, dyers, and cleaners exposed to solvents.

Occupation of father was not known for 30 cases (12 with no mention of occupation on birth certificate, 3 with a father not working at the time of birth, 15 with an unmarried mother) and 56 controls $(30,1$, and 25 respectively).

\section{Results}

The distributions of occupation of father at the time of birth for cases and controls differ 
TABLE I

DISTRIBUTION OF OCCUPATION OF FATHER AT TIME OF BIRTH FOR CASES AND CONTROLS

\begin{tabular}{|c|c|c|c|c|c|}
\hline \multirow[b]{2}{*}{$\begin{array}{l}\text { Occupation of Father } \\
\text { at Time of Birth }\end{array}$} & \multicolumn{2}{|c|}{ Cases } & \multicolumn{2}{|c|}{ Controls } & \multirow{2}{*}{$\begin{array}{l}\text { Total } \\
\text { No. }\end{array}$} \\
\hline & No. & $\%$ & No. & $\%$ & \\
\hline 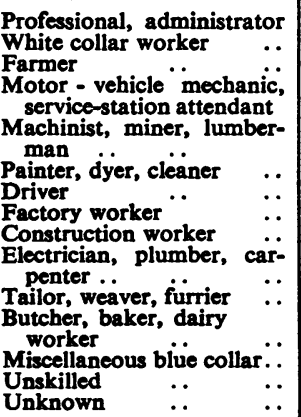 & $\begin{array}{r}18 \\
82 \\
28 \\
29 \\
32 \\
10 \\
19 \\
16 \\
8 \\
26 \\
8 \\
12 \\
19 \\
49 \\
30\end{array}$ & $\begin{array}{r}4 \cdot 7 \\
21 \cdot 2 \\
7 \cdot 3 \\
7 \cdot 5 \\
8 \cdot 3 \\
2 \cdot 6 \\
4 \cdot 9 \\
4 \cdot 1 \\
2 \cdot 1 \\
6 \cdot 7 \\
2 \cdot 1 \\
3 \cdot 1 \\
4 \cdot 9 \\
12 \cdot 7 \\
7 \cdot 8\end{array}$ & $\begin{array}{r}59 \\
167 \\
78 \\
29 \\
35 \\
11 \\
49 \\
34 \\
19 \\
63 \\
8 \\
25 \\
43 \\
96 \\
56\end{array}$ & $\begin{array}{r}7 \cdot 6 \\
21 \cdot 6 \\
10 \cdot 1 \\
3 \cdot 8 \\
4 \cdot 5 \\
1 \cdot 4 \\
6 \cdot 4 \\
4 \cdot 4 \\
2 \cdot 5 \\
8 \cdot 2 \\
1 \cdot 0 \\
3 \cdot 2 \\
5 \cdot 6 \\
12.4 \\
7 \cdot 3\end{array}$ & $\begin{array}{r}77 \\
249 \\
106 \\
58 \\
67 \\
21 \\
68 \\
50 \\
27 \\
89 \\
16 \\
37 \\
62 \\
145 \\
86\end{array}$ \\
\hline Total ... & 386 & $100 \cdot 0$ & 772 & $100 \cdot 0$ & 1,158 \\
\hline
\end{tabular}

significantly at the 0.05 level (Table I). The larger contributions to $\chi^{2}$ come from four of the cells corresponding to hydrocarbon-related occupations. In those cells (motor-vehicle mechanics and servicestation attendants, machinists, miners, and lumbermen) the expected numbers are much lower than the observed ones for cases and, of course, the reverse is true for controls. Out of a total $\chi^{2}$ of $25 \cdot 31$, the six cells corresponding to hydrocarbonrelated occupations account for $15 \cdot 47$ whereas the 24 remaining cells contribute $9 \cdot 84$.

Partitioning the 14 degrees of freedom into 11 degrees to compare distributions of occupations classified as not exposed to hydrocarbons, 2 degrees to compare distributions of occupations classified as exposed, and 1 degree of freedom to compare distributions of exposed versus non-exposed occupations, the first and second $\chi^{2}$ show no significant differences $\left(\chi^{2}=7 \cdot 90,11 \mathrm{DF}, \mathrm{P}>0.70 ; \chi^{2}=0.07\right.$, $2 \mathrm{DF}, \mathrm{P}>0.95)$ whereas the third is highly significant $\left(\chi^{2}=16.81\right.$ with Yates' correction, $1 \mathrm{DF}$, $P<0.0001)$. The relative odds are $2 \cdot 1$ for the exposed occupations.

The detailed distribution of fathers in hydrocarbon-related occupations for cases and controls is shown in Table II. Excesses for cases exist mainly among motor-vehicle mechanics, machinists, miners, and painters.

The distribution of occupation of fathers for cases by diagnosis appears in Table III. The excess of fathers in the motor-vehicle mechanic group exists in all diagnostic categories with the exception of Wilms' tumour; in the machinist group, it exists for leukaemia and for 'others'.

Five cases of Letterer-Siwe disease have been included in this series in the diagnostic group labelled 'others'. Four of the fathers were in hydrocarbon-related occupations-two painters, one motor-vehicle mechanic, and one miner; the fifth was a weaver.

TABLE II

DISTRIBUTION OF HYDROCARBON-RELATED OCCUPATION OF FATHER FOR CASES AND CONTROLS

\begin{tabular}{|c|c|c|c|c|c|c|}
\hline \multicolumn{4}{|c|}{$\begin{array}{c}\text { Occupation of Father at Time of } \\
\text { Birth }\end{array}$} & \multirow{2}{*}{$\begin{array}{r}\text { Cases } \\
28 \\
1 \\
24 \\
6 \\
2 \\
8 \\
1 \\
1\end{array}$} & \multirow{2}{*}{$\begin{array}{c}\text { Controls } \\
27 \\
2 \\
29 \\
6 \\
\frac{7}{7} \\
1 \\
3\end{array}$} & \multirow{2}{*}{$\begin{array}{r}\text { Total } \\
55 \\
3 \\
53 \\
12 \\
2 \\
15 \\
2 \\
4\end{array}$} \\
\hline $\begin{array}{l}\text { Motor-vehicle } \\
\text { Service-statio } \\
\text { Machinist } \\
\text { Miner . . } \\
\text { Lumberman } \\
\text { Painter . . } \\
\text { Dyer . } \\
\text { Cleaner }\end{array}$ & $\begin{array}{l}\text { echanic } \\
\text { ttendant } \\
\ldots \\
\ldots \\
\ldots \\
\ldots \\
\ldots\end{array}$ & $\begin{array}{c}\ldots \\
\ldots \\
\ldots \\
\ldots \\
\ldots\end{array}$ & $\begin{array}{l}\ldots \\
\ldots \\
\ldots \\
\cdots \\
\cdots \\
\cdots\end{array}$ & & & \\
\hline Total $\ldots$ & . & $\cdots$ & . & 71 & 75 & 146 \\
\hline
\end{tabular}

TABLE III

DISTRIBUTION OF OCCUPATION OF FATHER AT TIME OF BIRTH FOR CASES BY DIAGNOSIS

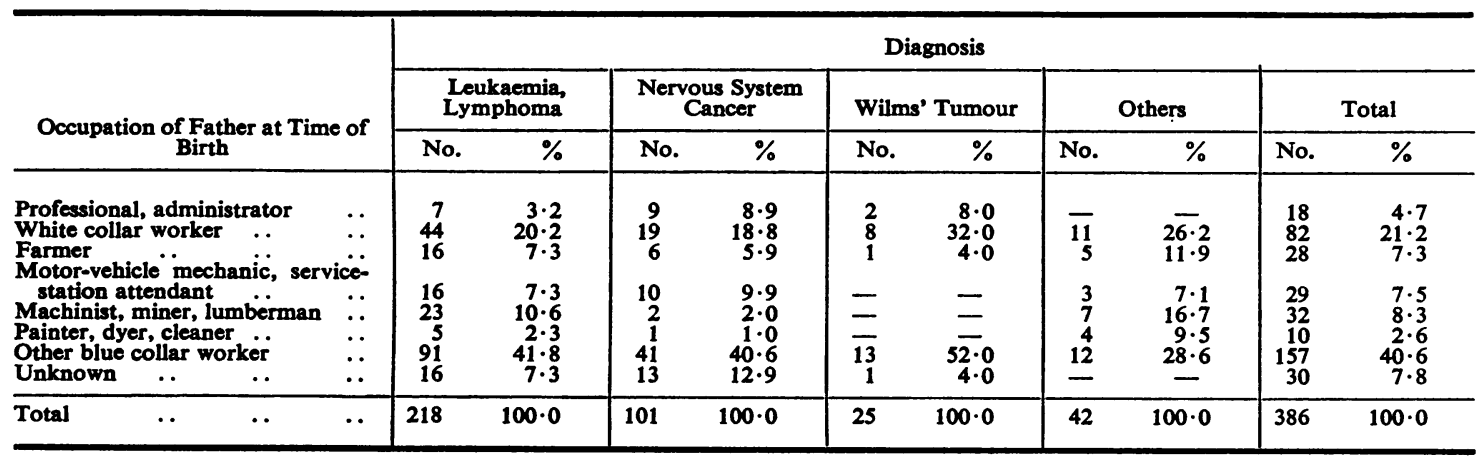


The geographical distribution of residence of the parents at the time of birth of cases and controls did not differ nor did the distribution of paternal and maternal age. The mean paternal age was 31.46 years with a standard deviation of 6.8 for cases and 31.44 with a standard deviation of 6.9 for controls. In the blue-collar worker group, the mean paternal age was 30.89 years for cases and 31.00 for controls with standard deviations of 6.8 and 7.0 respectively.

How the exposure of the father to hydrocarbons could lead to a greater risk of malignant disease among his offspring is open to question. Could it be because the child is himself exposed to the repeated or continued presence of certain items in the household or prolonged contact with his father? Could it be the result of a direct effect of some hydrocarbon contained in petrol and oil on spermatogenesis - the carcinogenetic defect would then be transmitted to the child?

Although the results of this study are quite striking, the well known difficulties in classifying occupations plus the possibility that there may be something unusual about this series of cases and/or controls should be kept in mind. Considering the potential interest of the problem, further investigation on this topic would seem to be warranted.

The authors wish to thank Dr. Jean-Marc Fredette and the staff of the Quebec Population Register for their co-operation and Dr. Gilles Thériault for valuable advice.

\section{REFERENCES}

Fasal, E., Jackson, E. W., and KLAUBer, M. R. (1971). Birth characteristics and leukemia in childhood. J. nat. Cancer Inst., 47, 501.

Githens, J. H., Elliot, F. E. and Saunders, L. H. (1965). The relation of socio-economic factors to incidence of childhood leukemia. Publ. Hlth Rep. (Wash.), 80, 573.

Pinkre, D. and NefzGer, D. (1959). Some epidemiological features of childhood leukemia in the Buffalo, N.Y., area. Cancer (Philad.), 12, 351.

Stewart, A., WebB, J., and HewitT, D. (1958). A survey of childhood malignancies. Brit. med. J., 1 , 1495. 